\title{
CDK6/MLL Fusion Gene
}

National Cancer Institute

\section{Source}

National Cancer Institute. CDK6/MLL Fusion Gene. NCI Thesaurus. Code C99589.

A fusion gene that results from a complex chromosomal aberration which fuses exon 2 of the CDK6 gene with exon 10 of the MLL gene. This fusion may be associated with infant acute lymphoblastic leukemia. 